\title{
A NATUREZA JURÍDICA DOS BENEFÍCIOS FISCAIS DA ZONA FRANCA DE MANAUS (ZFM): Imunidade Tributária ou Isenção
}

\author{
THE LEGAL NATURE OF THE TAX BENEFITS OF THE MANAUS FREE ZONE \\ (ZFM): \\ Tax Immunity or Exemption
}

\author{
Jofre Luis da Costa Oliveira ${ }^{1}$
}

\section{RESUMO}

O modelo ZFM pode ser considerado um exemplo de política pública bem-sucedida por ter contribuído, ao longo dos últimos 50 anos, para o desenvolvimento da região. O presente artigo versa sobre a natureza jurídica dos incentivos fiscais oferecidos pela ZFM. A discussão sobre esse tema é palpitante e muito importante para o futuro do Estado e da Região, bem como para o Brasil, que atravessa uma delicada situação de ajuste, principalmente nas contas públicas e no sistema tributário, que beiram o colapso. Os objetivos do presente estudo são: apresentar o modelo ZFM, focalizando suas peculiaridades; analisar os conceitos de isenção e de imunidade tributária, estabelecendo as principais diferenças entre esses institutos; apresentar os diversos julgados do STF que abordam a natureza jurídica dos incentivos fiscais na ZFM; e apresentar todos os incentivos nos níveis federal, estadual e municipal, estabelecendo a natureza jurídica deles. A metodologia adotada utilizou a pesquisa bibliográfica, valendo-se do método hipotéticodedutivo com o objetivo de analisar os conceitos de isenção e de imunidade tributária para chegar à definição de qual seria a natureza tributária dos incentivos do modelo ZFM. Ainda que este trabalho não tenha a pretensão de esgotar o assunto, pretende despertar o interesse quanto à preservação e ao aprimoramento desse modelo que, a despeito de alguns críticos, muito tem contribuído para reduzir as desigualdades regionais.

Palavras-Chave: Zona Franca de Manaus (ZFM). Natureza Jurídica dos Incentivos Fiscais da ZFM. Desenvolvimento Regional. Políticas Públicas. Direito Constitucional. Direito Tributário.

\section{ABSTRACT}

The ZFM model can be considered as an example of successful public policy, as it has contributed, over the last 50 years, to the development of the region. This article deals with the legal nature of the tax incentives offered by ZFM. The discussion on this topic is current and very important for the future of the State and the Region, as well as for Brazil, which is going through a delicate situation of adjustments, mainly in public accounts, and in the tax system that borders on collapse. The objectives of the present study are: to present the ZFM model, emphasizing its peculiarities; analyze the concept of tax exemption and immunity, establishing the main differences between these institutes; present the various STF judgments that address the legal nature of ZFM tax incentives; present all the incentives at the different levels (union, state and municipality) establishing their legal nature. The methodology used was based on bibliographic research, using the hypothetical-deductive method in order to analyze the different concepts of tax exemption and immunity and arrive at a definition of the tax nature of the incentives of the ZFM model. We consider that the present work does not intend to exhaust the

\footnotetext{
${ }^{1}$ Graduação em Economia (UFAM), Graduação em Direito (UFAM), Pós graduação - Mba em Finanças - IBMEC, Pós Graduação em Direito Publico - UFAm, Mestrado em Economia - URGS e Mestrando em Direito (UFAM)
} 
subject, but to arouse the interest of all in the sense of preserving and improving the model that, despite some criticals, has contributed to the reduction of regional inequalities.

Keywords: Manaus Free Trade Zone (ZFM). Tax breaks. Regional development. Legal Nature of ZFM Tax Incentives. Public Policy. Constitutional Right. Tax Law.

\section{INTRODUÇÃO}

O presente artigo versa sobre a natureza jurídica dos incentivos fiscais oferecidos pelo modelo ZFM. A escolha do tema se justifica em razão de tal modelo de ser um exemplo de política pública bem-sucedida que, sem dúvidas, vem contribuindo para o desenvolvimento da região Norte.

Assim, compreender a natureza jurídica dos incentivos concedidos é fundamental para atuar na defesa da ZFM contra constantes investidas de outras regiões que desejam o fim desse modelo, além de contribuir para o surgimento de propostas com vistas ao seu aprimoramento. A discussão sobre esse tema é atual e muito importante para o futuro do Amazonas e da região, bem como para o país, pois este atravessa uma delicada situação de ajustes, principalmente nas contas públicas e no sistema tributário, que estão à beira do colapso.

Os objetivos do presente estudo são: apresentar o modelo ZFM, enfatizando suas peculiaridades; analisar os conceitos doutrinários de isenção e de imunidade tributária, a fim de estabelecer as principais diferenças entre os institutos; apresentar os diversos julgados do STF que abordam a natureza jurídica dos incentivos fiscais da ZFM; listar os incentivos concedidos nos três níveis (federal, estadual e municipal), estabelecendo a natureza jurídica de cada um.

A metodologia adotada utilizou-se da pesquisa bibliográfica, valendo-se do método hipotético-dedutivo para compreender os diferentes conceitos de isenção e imunidade tributária e, finalmente, chegar a uma definição sobre a natureza tributária dos incentivos do modelo.

$\mathrm{O}$ artigo foi divido em duas seções. Na primeira, versa-se sobre os principais aspectos históricos, sobretudo detalhando as características das quatro fases pelas quais o modelo passou. Ainda nessa seção, são analisadas as prorrogações no prazo estabelecido para a existência da Zona Franca. Por fim, são apresentados os tipos de incentivos fiscais ofertados pela ZFM.

$\mathrm{Na}$ segunda seção, o propósito é identificar a natureza jurídica dos benefícios da ZFM. Inicialmente, busca-se na doutrina atual os conceitos de isenção e de imunidade tributária, bem como se estabelece a distinção entre tais institutos, de acordo com diversos doutrinadores. Em seguida, o foco passa a ser nas decisões que têm sido proferidas pelo STF acerca dos incentivos da ZFM, passando, a partir de todos esses subsídios, a definir a natureza jurídica dos incentivos da ZFM, se de isenção ou de imunidade tributária. Como principal contribuição, apresenta-se uma síntese da temática abordada com enfoque no modelo ZFM, traçando um paralelo entre os benefícios concedidos, seus fundamentos constitucionais/legais e suas naturezas jurídicas.

\section{ASPECTOS GERAIS DA ZONA FRANCA DE MANAUS}

O modelo ZFM foi criado pelo Decreto-Lei n. 288, de 28 de fevereiro de 1967, com a finalidade de criar uma área de livre comércio de importação e exportação e de incentivos fiscais especiais, conforme dispõe o artigo $1^{\circ}$ do referido DL:

Das finalidades e localização da Zona Franca de Manaus

Art. $1^{\circ}$. A Zona Franca de Manaus é uma área de livre comércio de importação e exportação e de incentivos fiscais especiais, estabelecida com a finalidade de criar no interior da Amazônia um centro industrial, comercial e agropecuário dotado de condições econômicas 


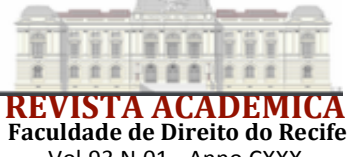

Vol. 93 N.01 - Anno CXXX

que permitam seu desenvolvimento, em face dos fatores locais e da grande distância, a que se encontram, os centros consumidores de seus produtos.

A Superintendência da Zona Franca de Manaus (SUFRAMA) ${ }^{2}$ assevera que o modelo pode ser configurado em quatro fases ${ }^{3}$ distintas até chegar à atual. Na primeira delas (de 1967 a 1975), havia uma política industrial de referência no país caracterizada pelo estímulo à substituição de importações de bens finais e à formação de um mercado interno. O modelo ZFM apresentou, à época, os seguintes aspectos relevantes: predominância da atividade comercial e, fundamentalmente, início da atividade industrial, com atividade baseada em CKD (Completely Knocked Down) e em SKD (Semi Knocked Down).

A segunda fase compreendeu o período de 1975 a 1990. Nesta fase, a política industrial de referência no país era caracterizada pela adoção de medidas com vistas a fomentar a indústria nacional de insumos, sobretudo no estado de São Paulo.

O modelo ZFM passou a ter as seguintes características principais:

- Foram estabelecidos os Índices Mínimos de Nacionalização para os produtos industrializados na ZFM e comercializados nas demais localidades do território nacional;

- Foram estabelecidos, ainda, limites máximos globais anuais de importação (contingenciamento);

- Os incentivos do modelo ZFM são estendidos para a Amazônia Ocidental;

- Foi criada a primeira das sete Áreas de Livre Comércio (ALC's), em Tabatinga, Amazonas, conforme a Lei n ${ }^{\circ} 7.965 / 89$;

- Foi prorrogado, pela primeira vez, o prazo de vigência do modelo ZFM, de 1997 para 2007, por meio do Decreto $n^{\circ}$ 92.560, de 16 de abril de 1986. Em 1998, por meio do Artigo 40 do Ato das Disposições Transitórias da Constituição Federal, o prazo foi prorrogado para até 2013.

A terceira fase compreendeu os anos entre 1991 e 1996. Nesta fase, entrou em vigor a Nova Política Industrial e de Comércio Exterior, marcada pela abertura da economia brasileira, pela redução do Imposto de Importação para o restante do país e pela ênfase na qualidade e produtividade. Nesse período é que foram implantados o Programa Brasileiro de Qualidade e Produtividade (PBPQ) e o Programa de Competitividade Industrial.

A edição da Lei n. 8.387, de 30 de dezembro de 1991, estabeleceu profundas mudanças no modelo ZFM, obrigando-o a se adaptar à política industrial de referência que passou a viger no país. Pode-se atribuir as seguintes características ao modelo nesta terceira fase:

- Perda de relevância do comércio, que deixou de ter a exclusividade das importações como vantagem comparativa;

- Eliminação dos limites máximos globais anuais de importação, por meio do Decreto $\mathrm{n}^{\circ}$ 205, de 5 de setembro de 1991;

- Adoção de redutor de $88 \%$ do Imposto de Importação para a ZFM, com a edição da Lei 8.387 de 30 de dezembro de 1991;

- Adoção do Processo Produtivo Básico (PPB), em substituição ao Índice Mínimo de Nacionalização;

\footnotetext{
${ }^{2}$ A partir de 1989, a Superintendência da Zona Franca de Manaus (SUFRAMA), que administra o modelo, passou a abrigar em sua área de jurisdição sete Áreas de Livre Comércio (ALC's), criadas com o objetivo promover o desenvolvimento de municípios que são fronteiras internacionais na Amazônia e integrá-los ao restante do país, por meio da extensão de alguns benefícios fiscais do modelo ZFM, da melhoria na fiscalização de entrada e saída de mercadorias e do fortalecimento do setor comercial, agroindustrial e extrativo.

${ }^{3}$ Histórico da ZFM. Disponível em: http://www.suframa.gov.br/zfm_historia.cfm. Acesso em: $1^{\circ}$ jan. 2020.
} 
- A Lei 8.387/91 também estabeleceu que as indústrias de produção de bens e serviços de informática, para fazer jus aos incentivos do modelo ZFM, devem aplicar, anualmente, no mínimo 5\% do seu faturamento bruto em atividades de pesquisa e desenvolvimento a serem realizadas na Amazônia;

- As empresas do Pólo Industrial de Manaus deram início a um amplo processo de modernização industrial, com ênfase na automação, qualidade e produtividade;

- Em 1996, a reestruturação do parque fabril refletiu em faturamento recorde para aquela década, da ordem de US\$13,2 bilhões;

- Foi criada a Área de Livre Comércio de Macapá-Santana, no Amapá, únicos municípios da Amazônia Oriental que integram a área de jurisdição da SUFRAMA.

$\mathrm{Na}$ quarta fase, que compreendeu o período entre 1996 e 2002, a política industrial de referência do país estava marcada pela adaptação aos cenários de uma economia globalizada e pelos ajustes ainda demandados pelos efeitos do Plano Real (1994), tais como o movimento de privatizações e de desregulamentação.

Nesta fase quarta fase, o modelo ZFM tinha como principais características:

- A inclusão da função exportação como política intencional, com objetivo de estimular as vendas externas do Pólo Industrial de Manaus, que saíram de pouco mais de US\$ 140 milhões em 1996 para US\$ 2 bilhões em 2005;

- Esgotamento das ALC's como instrumentos de interiorização do modelo ZFM. Nos moldes em que foram criadas, com incentivos para importação, perderam relevância com a abertura da economia do país;

- Estabelecimento de critérios para repasse de recursos financeiros da SUFRAMA para promoção do desenvolvimento regional, por meio da Resolução n. 052, de 01 de agosto de 1997, tornando a distribuição mais equânime;

- Busca de ampliação da competitividade tecnológica das indústrias de Manaus, que teve como marco inicial a criação do Centro de Ciência, Tecnologia e Inovação do Pólo Industrial de Manaus (CT-PIM);

- Iniciativas para criação de um polo de bioindústrias na Amazônia que culminou com a implantação do Centro de Biotecnologia da Amazônia, inaugurado em 2002.

Na chamada fase atual do modelo ZFM, passa a vigorar a Política de Desenvolvimento Produtivo (PDP) em aprofundamento da Política Industrial Tecnológica e de Comércio Exterior (PITCE), que prevê maior eficiência produtiva, mais capacidade de inovação das empresas e a expansão das exportações. A PDP definiu macrometas para o Brasil que, até este ano de 2010, previam um aumento da formação bruta de capital fixo, maior dispêndio do setor privado em pesquisa e desenvolvimento (P\&D) e uma ampliação das exportações brasileiras, em especial, para as micro e pequenas empresas. São características desta fase atual:

- O prazo de vigência do modelo foi prorrogado de 2013 para 2023, por meio da Emenda Constitucional n. 42, de 19 de dezembro de 2003;

- A definição de Processos Produtivos Básicos (PPBs) para produtos fabricados no PIM é orientada pelo maior adensamento de cadeias produtivas nacionais, inclusive dos biocosméticos;

- Permanece a busca pelo aumento das exportações e maior equilíbrio da balança comercial; 


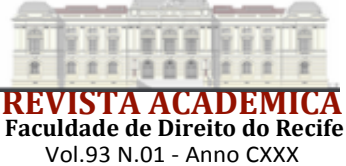

- Há um esforço das indústrias do PIM em fomentar o adensamento tecnológico do parque industrial, por meio de investimentos em institutos de pesquisa regionais, sobretudo advindos de recursos do percentual destinado à Pesquisa e Desenvolvimento (P\&D), determinado pela Lei de Informática em vigor;

- Ampliam-se os investimentos da SUFRAMA em projetos de modernização produtiva e infraestrutural nos municípios da sua área de atuação, envolvendo construção de aeroportos, estradas, estruturas turísticas, projetos pilotos de produção e capacitação de mão-de-obra.

Inicialmente, a ZFM foi concebida para durar 30 anos, entretanto, tal prazo vem sendo prorrogado. A primeira prorrogação se deu com a edição do Decreto n. 92.560, 16 de abril de 1986 - no governo José Sarney. Logo em seu art.1 ${ }^{\circ}$, o referido Decreto prorrogou os incentivos por mais uma década. Dessa forma, os inventivos fiscais da ZFM, que vigorariam até fevereiro de 1997, tiveram seu prazo de concessão prolongado até fevereiro de 2007.

A partir da promulgação da Constituição Federal de 1988, o prazo de vigência da ZFM passou a ser até 5 de outubro de 2013, conforme previsto no art. 40 do Ato das Disposições Transitórias (ADC) ${ }^{4}$. Finalmente, a Emenda Constitucional n. 83/2014 estendeu o prazo da ZFM até o dia 05 de outubro de 2073, conforme dispõe o art. 92-A do ADCT.

Na lição de Ramos Filho (2019, p. 40) o prazo previsto no art. 42 do DL 288/1967 não poderia ser prorrogado por decreto do Poder Executivo, já que fora consignado, expressamente, um novo prazo para vigência da ZFM no próprio texto Constitucional. Dessa forma, o referido prazo somente poderia ser prorrogado por meio de Emenda Constitucional.

Neste ponto, necessário salientar que as regras previstas no ADCT possuem o mesmo "status" de normas que se encontram no corpo da Constituição Federal de 1988, apesar de serem qualificadas como transitórias. Nesse sentido já decidiu o STF no RE 160.486/SP:

PRECATÓRIO - PAGAMENTO PARCELADO - ADCT, ART. 33 NATUREZA JURÍDICA DAS NORMAS INTEGRANTES DO ADCT RELAÇÕES ENTRE O ADCT E AS DISPOSIÇÕES PERMANENTES DA CONSTITUIÇÃO - ANTINOMIA APARENTE - A QUESTÃO DA COERÊNCIA DO ORDENAMENTO POSITIVO - RECURSO EXTRAORDINÁRIO CONHECIDO E PROVIDO. - Os postulados que informam a teoria do ordenamento jurídico e que lhe dão o necessário substrato doutrinário assentam-se na premissa fundamental de que o sistema de direito positivo, além de caracterizar uma unidade institucional, constitui um complexo de normas que devem manter entre si um vínculo de essencial coerência. O Ato das Disposições Transitórias, promulgado em 1988 pelo legislador constituinte, qualifica-se, juridicamente, como um estatuto de índole constitucional. A estrutura normativa que nele se acha consubstanciada ostenta, em consequência, a rigidez peculiar às regras inscritas no texto básico da Lei Fundamental da República. Disso decorre o reconhecimento de que inexistem, entre as normas inscritas no ADCT e os preceitos constantes da Carta Política, quaisquer desníveis ou desigualdades quanto à intensidade de sua eficácia ou à prevalência de sua autoridade. Situam-se, ambos, no mais elevado grau de positividade jurídica (BRASIL. Supremo Tribunal Federal. RE 160.486/SP, grifo nosso).

\footnotetext{
${ }^{4}$ Art.40.É mantida a Zona Franca de Manaus, com suas características de área livre de comércio, de exportação e importação, e de incentivos fiscais, pelo prazo de vinte e cinco anos, a partir da promulgação da Constituição.

Parágrafo único. Somente por lei federal podem ser modificados os critérios que disciplinaram ou venham a disciplinar a aprovação dos projetos na Zona Franca de Manaus.
} 
Como a ZFM foi expressamente recepcionada pelo art. 40 do ADCT, o que garantiu sua proteção constitucional, os princípios constitucionais podem e devem ser utilizados para propiciar a melhor interpretação de suas normas e do seu relacionamento com outras normas.

Nesse seguimento, Ramos Filho (2019, p.19-20) sustenta que os fundamentos gerais que são sustentáculos da ZFM encontram-se inseridos no inciso II do art. $3^{\circ}$ e no inciso VII do artigo 170 da Constituição Federal de 1988. Tais dispositivos estabelecem, respectivamente, a redução das desigualdades regionais como objetivo fundamental da República Federativa do Brasil e como princípio da ordem econômica, in verbis:

Art. $3^{\circ}$ Constituem objetivos fundamentais da República Federativa do Brasil:

I - construir uma sociedade livre, justa e solidária;

II - garantir o desenvolvimento nacional;

III - erradicar a pobreza e a marginalização e reduzir as desigualdades sociais e regionais (grifo nosso)

(...)

Art. 170. A ordem econômica, fundada na valorização do trabalho humano e na livre iniciativa, tem por fim assegurar a todos existência digna, conforme os ditames da justiça social, observados os seguintes princípios:

I - soberania nacional;

II - propriedade privada;

III - função social da propriedade;

IV - livre concorrência;

$\mathrm{V}$ - defesa do consumidor;

VI - defesa do meio ambiente;

VI - defesa do meio ambiente, inclusive mediante tratamento diferenciado conforme o impacto ambiental dos produtos e serviços e de seus processos de elaboração e prestação;(Redação dada pela Emenda Constitucional nº 42, de 19.12.2003)

VII - redução das desigualdades regionais e sociais (BRASIL, 1988, grifo nosso).

Ademais, há outros dispositivos que estão inseridos na Carta Magna e que justificam plenamente a existência da ZFM, são eles: art. $43, \S 2^{\circ}$, III; e, fundamentalmente, o art. 151, I da $\mathrm{CF} / 88$. A seguir, transcrevem-se os dispositivos mencionados:

Art. 43. Para efeitos administrativos, a União poderá articular sua ação em um mesmo complexo geoeconômico e social, visando a seu desenvolvimento e à redução das desigualdades regionais.

$\S 1^{\circ}$ Lei complementar disporá sobre:

I - as condições para integração de regiões em desenvolvimento;

II - a composição dos organismos regionais que executarão, na forma da lei, os planos regionais, integrantes dos planos nacionais de desenvolvimento econômico e social, aprovados juntamente com estes.

$\S 2^{\circ}$ Os incentivos regionais compreenderão, além de outros, na forma da lei:

I - igualdade de tarifas, fretes, seguros e outros itens de custos e preços de responsabilidade do Poder Público;

II - juros favorecidos para financiamento de atividades prioritárias;

III - isenções, reduções ou diferimento temporário de tributos federais devidos por pessoas físicas ou jurídicas;

IV - prioridade para o aproveitamento econômico e social dos rios e das massas de água represadas ou represáveis nas regiões de baixa renda, sujeitas a secas periódicas. (BRASIL, 1988, grifo nosso). 
Art. 151. É vedado à União:

I - instituir tributo que não seja uniforme em todo o território nacional ou que implique distinção ou preferência em relação a Estado, ao Distrito Federal ou a Município, em detrimento de outro, admitida a concessão de incentivos fiscais destinados a promover o equilíbrio do desenvolvimento sócio-econômico (sic) entre as diferentes regióes do País. (BRASIL, 1988, grifo nosso).

Ressalta-se: todo o elenco pré-constitucional de incentivos da ZFM foi devidamente recepcionado pelo art. 40 do ADCT. Tal assertiva se demonstra pela ementa do julgado da Ação Direta de Inconstitucionalidade a respeito dos convênios de ICMS n. 01, 02 e 06 de 1990:

AÇÃO DIRETA DE INCONSTITUCIONALIDADE. CONVÊNIOS SOBRE ICMS NS. 01, 02 E 06 DE 1990: REVOGAÇÃO DE BENEFÍCIOS FISCAIS INSTITUIIDOS ANTES DO ADVENTO DA ORDEM CONSTITUCIONAL DE 1998, ENVOLVENDO BENS DESTINADOS À ZONA FRANCA DE MANAUS. (...) 2. O quadro normativo pré-constitucional de incentivo fiscal à Zona Franca de Manaus constitucionalizou-se pelo art. 40 do Ato das Disposições Constitucionais Transitórias, adquirindo, por força dessa regra transitória, natureza de imunidade tributária, persistindo vigente a equiparação procedida pelo art. $4^{\circ}$ do Decreto-Lei n. 288/1967, cujo propósito foi atrair a não incidência do imposto sobre circulação de mercadorias estipulada no art. 23, inc. II, $\S 7^{\circ}$, da Carta pretérita, desonerando, assim, a saída de mercadorias do território nacional para consumo ou industrialização na Zona Franca de Manaus. 3. A determinação expressa de manutenção do conjunto de incentivos fiscais referentes à Zona Franca de Manaus, extraídos, obviamente, da legislação préconstitucional, exige a não incidência do ICMS sobre as operações de saída de mercadorias para aquela área de livre comércio, sob pena de se proceder a uma redução do quadro fiscal expressamente mantido por dispositivo constitucional específico e transitório. 4. Ação direta de inconstitucionalidade julgada procedente (DJe 9/9/14).

No mesmo sentido, vide: RE $\mathrm{n}^{\circ} 1.028 .287 / \mathrm{SC}$, de minha relatoria, DJe de 5/4/17; RE $n^{\circ} 1.021 .164 / \mathrm{RS}$, Rel. Min. Rosa Weber, DJe de 2/3/17; RE $\mathrm{n}^{\mathrm{o}}$ 1.026.463/RS, Rel. Min. Rosa Weber, DJe de 10/3/17; RE n ${ }^{\circ}$ 1.023.826/RS, Rel. Min. Edson Fachin, DJe de 6/3/17; RE n ${ }^{\circ}$ 996.142/SC, Rel. Min. Celso de Mello, DJe de 3/10/16; RE n ${ }^{\circ}$ 984.999/SC, Rel. Min. Ricardo Lewandowski, DJe de 27/9/16; RE n ${ }^{\circ}$ 925.863/RS, Rel. Min. Roberto Barroso, DJe de 1\%/12/15.

Assim, não restam dúvidas que o modelo ZFM foi inteiramente "constitucionalizado", haja vista que a constituição pretérita não se posicionou sobre essa temática. Na lição de Ramos Filho (2019, p. 27), a atual Constituição brasileira:

É a única, em toda a história constitucional do País, na qual foi feita expressa menção à Zona Franca de Manaus. Nela pode reunir as bases constitucionais da ZFM em dois grupos: a) os fundamentos gerais, assim considerados por não se referirem especificamente à ZFM; e b) os fundamentos específicos.

Significa dizer que a temática específica sobre a Zona Franca de Manaus tomou lugar com a promulgação da Carta Magna de 1988, sendo somente a partir daí que tal modelo passou a ser regulado em nível constitucional, o que lhe garante, hoje, maior segurança jurídica.

\subsection{TIPOS DE INCENTIVOS}


A ZFM oferta uma gama de incentivos que poderiam ser classificados como sendo de natureza fiscal e extrafiscal, sendo-lhe ofertados a partir das três esferas de governo. Além dos incentivos proporcionados pelo governo federal, o modelo também dispõe de incentivos nos âmbitos do estado do Amazonas e do município de Manaus (SUFRAMA- 2019). Nas subseções seguintes, são relacionados os benefícios de natureza fiscal oferecidos pelos entes.

\subsubsection{Tributos Federais}

1) Redução de até $88 \%$ do Imposto de Importação (I.I.) sobre os insumos destinados à industrialização;

2) Isenção do Imposto sobre Produtos Industrializados (I.P.I.);

3) Redução de $75 \%$ do Imposto de Renda de Pessoa Jurídica (IRPJ), inclusive adicionais de empreendimentos classificados como prioritários para o desenvolvimento regional, calculados com base no Lucro da Exploração até 2013;

4) Isenção da contribuição para o PIS/PASEP e da Cofins nas operações internas na Zona Franca de Manaus.

\subsubsection{Tributos Estaduais}

Restituição parcial ou total, variando de $55 \%$ a $100 \%$ - percentil a depender do projeto do Imposto sobre Operações Relativas à Circulação de Mercadorias e sobre Prestação de Serviços de Transporte Interestadual e Intermunicipal e de Comunicação (ICMS).

\subsubsection{Tributos Municipais}

Isenção do Imposto sobre a Propriedade Predial e Territorial Urbana (IPTU), Taxas de Serviços de Coleta de Lixo, de Limpeza Pública, de Conservação de Vias e Logradouros Públicos e Taxas de Licença para as empresas que geram um mínimo de quinhentos empregos, de forma direta, no início de sua atividade, mantendo esse número durante o gozo do benefício. (Lei Municipal no 427/1998, da cidade de Manaus).

\subsubsection{Demais incentivos (extrafiscais)}

Como incentivos extrafiscais oferecidos no modelo ZFM estão: no parque industrial de Manaus (PIM), o investidor tem à disposição terreno a preço simbólico, com infraestrutura de captação e tratamento de água, sistema viário urbanizado, rede de abastecimento de água, rede de telecomunicações, rede de esgoto sanitário e drenagem pluvial (SUFRAMA, 2019).

A área industrial na Zona Franca é de 3,9 mil hectares, mas, atualmente, as empresas lá instaladas ocupam uma área menor que 1,7 hectares. Consequentemente, conclui-se que estão disponíveis para receber novos empreendimentos mais de 2,2 hectares.

Além disso, foi criado em 1992, o Entreposto Internacional da Zona Franca de Manaus (Eizof), que funcionou provisoriamente de 1993 até o início dos anos 2000, no Porto de Manaus, quando foi incorporado à Estação Aduaneira do Interior (Eadi). O projeto arquitetônico original foi adequado à nova realidade orçamentária e às exigências de um mercado mais competitivo e exigente. Ele será implantado numa área de 300 mil metros quadrados, localizada no terreno da extinta Companhia Siderúrgica da Amazônia (Siderama), no Distrito Industrial.

Segundo a Suframa (2019), o Eizof funcionará em uma área contígua à que está reservada ao novo Porto de Cargas de Manaus, formando um complexo portuário importante para o Pólo Industrial de Manaus e para toda a Amazônia Ocidental do ponto de vista logístico. O entreposto 
terá a infraestrutura básica necessária para recepção, armazenagem e distribuição de cargas e de mercadorias nacionais e estrangeiras.

Além disso, há dois distritos disponíveis: o Industrial e o Agropecuário. No Distrito Industrial, é possível adquirir grandes áreas apropriadas a empreendimentos industriais a preços simbólicos e com prazo de até 12 meses para pagamento. Essa é uma das vantagens oferecidas ao investidor interessado em implantar seu projeto no Polo Industrial de Manaus. A área dispõe de infraestrutura de captação e de tratamento de água, sistema viário urbanizado, abastecimento de água, rede de telecomunicações, rede de esgoto sanitário e drenagem pluvial.

O Distrito Agropecuário foi criado em 1976, numa área de 589.33 hectares, ao Norte de Manaus. Sua finalidade é fornecer subsídios técnicos demonstrativos para a agricultura de terra firme na Amazônia e ampliar a oferta de produtos agropecuários dirigidos para o consumo em Manaus e também para a exportação.

Nesse Distrito, estão em implantação 624 projetos que geram 1.249 empregos diretos e 697 empregos indiretos, em atividades como: fruticultura, heveicultura, culturas alimentares, cacauicultura, olericultura e guaranaicultura (SUFRAMA, 2019).

Para viabilizar o projeto, o Governo Federal fez investimentos na abertura de estradas, no total de $571 \mathrm{~km}$, sendo: $69 \mathrm{~km}$ de estrada federal (BR-174), asfaltada e com energia elétrica; 468 $\mathrm{km}$ de estradas vicinais, construídos (108 km de rede elétrica) e $64 \mathrm{~km}$ projetados; e $34 \mathrm{~km}$ de estrada estadual (AM-010), asfaltada e com energia elétrica. Além disso, foram instaladas unidades avançadas de órgãos de pesquisa e extensão rural, tais como Ceplac, Embrapa, Inpa, Ibama $^{5}$ e Universidade Federal do Amazonas, além da Suframa e da Polícia Federal.

Na lição de Ramos Filho (2019, p.43), os benefícios da ZFM podem ser classificados nestes quatro grupos que a seguir são apresentados:

(i) Incentivos na entrada de mercadorias estrangeiras na ZFM;

(ii) Incentivos na remessa de mercadorias nacionais para a ZFM;

(iii) incentivos na saída de mercadorias produzidas na ZFM para qualquer ponto do território nacional; e

(iv) incentivos na exportação de mercadorias da ZFM para o exterior.

$\mathrm{Na}$ esfera estadual, conforme Ramos Filho (2019, p.148-149), os incentivos fiscais de ICMS concedidos pelo Governo do Estado do Amazonas possuem as seguintes características: a) condicionados; b) transitórios; c) regressivos; e d) graduais.

Em vista do panorama normativo, abrigado inclusive sob o manto constitucional, e da exposição dos incentivos ofertados nas três esferas (federal, estadual e municipal), convém esclarecer acerca da natureza jurídica dos benefícios fiscais da ZFM com detalhamento para, assim, passar à classificação dos incentivos partindo de uma ótica doutrinária e jurisprudencial.

\section{NATUREZA JURÍDICA DOS BENEFÍCIOS FISCAIS DA ZFM}

Antes de abordar qual seria a natureza jurídica dos benefícios oferecidos pelo modelo ZFM, convém dissertar a respeito do instituto da imunidade tributária, bem como da isenção e, fundamentalmente, estabelecer uma necessária comparação entre tais institutos.

$\mathrm{Na}$ lição de Paulo Barros de Carvalho (2019, p.215), a dogmática jurídico-tributária brasileira sempre estuda em conjunto os institutos da imunidade e da isenção. É comum estabelecer linhas paralelas entre ambos e chegar à conclusão que no final das contas o que resta é que inexiste o dever prestacional tributário, fato que, segundo ele, justifica o paralelismo entre

\footnotetext{
${ }^{5}$ Ceplac (Comissão Executiva do Plano da Lavoura Cacaueira); Embrapa (Empresa Brasileira de Pesquisa Agropecuária); Inpa (Instituto Nacional de Pesquisas da Amazônia); Ibama (Instituto Brasileiro do Meio Ambiente e dos Recursos Naturais Renováveis).
} 
os institutos. Contudo, o renomado doutrinador advoga que esse paralelo não se justifica, fundamentalmente porque existem pouquíssimas regiões de contato, são elas: a circunstância de serem normas jurídicas válidas no sistema; integrarem a classe das regras de estrutura; e tratarem de matéria tributária.

Além disso, o doutrinador assevera que existe uma distância abissal que separa essas duas espécies de unidades normativas. A imunidade exerce a função de colaborar no desenho das competências impositivas. São normas constitucionais, já a isenção se processa no plano da legislação ordinária, sendo, portanto, categorias jurídicas distintas.

Posição semelhante é adotada por Borges (2011, p.183), uma vez que ele assevera que nas hipóteses de não-incidência, o tributo não é devido porque não surge a própria obrigação tributária, entretanto ele defende que não há distinção entre isenção e imunidade, os dois institutos estariam envolvidos pelo manto da não-incidência, posicionamento minoritário em relação a doutrina. A diferença entre eles seria o tipo de diploma legal autorizativo. Se realizado por intermédio da constituição - imunidade-, caso contrário seria isenção.

\section{a. IMUNIDADE TRIBUTÁRIA}

Existe um consenso na doutrina e jurisprudência pátria sobre o conceito e o campo de abrangência da imunidade tributária. Na lição de José Souto Maior Borges (2011, p.46), o poder de tributar envolve o poder de isentar, portanto, a disciplina da isenção/imunidade deve obedecer fielmente aos princípios constitucionais da legalidade, da igualdade, da capacidade contribuitiva, entre outros.

Segundo Mazza (2019, p. 312), imunidades são normas constitucionais que limitam a competência tributária para afastar a incidência de tributos sobre determinados itens ou pessoas. Para o referido autor, as imunidades tributárias têm natureza dúplice, na medida em que são, ao mesmo tempo, limitações constitucionais ao poder estatal de tributar e, também garantias fundamentais do contribuinte.

Na lição de Sabbag (2012, p. 283), a imunidade para tributos revela uma delimitação negativa da competência tributária que decorre dos princípios e garantias constitucionais, que, dotados de expressiva carga axiológica, são vocacionados a limitar o poder de tributar. É dizer: a imunidade não exclui nem suprime competências tributárias, uma vez que estas representam o resultado de uma conjunção de normas constitucionais, entre elas, as de imunidade tributária.

Por seu turno, Alexandre (2019, p. 211) classifica as imunidades, relativamente ao parâmetro para a concessão, nas seguintes: imunidades subjetivas - relacionadas às pessoas beneficiadas pela exceção; imunidades objetivas - relacionados aos objetos, cuja tributação é impedida; e imunidades mistas - as duas coisas ao mesmo tempo.

Citam-se como exemplo: i. Subjetiva - a regra imunizante que impede a tributação de patrimônio, renda ou serviços dos entes políticos (CF, art.150, VI, a); ii. Objetiva - a imunidade que protege os livros, jornais, periódicos e o papel destinado à sua impressão $(\mathrm{CF}$, art.150, VI, d); iii. Mista, a imunidade que impede a incidência do imposto de Propriedade Territorial Rural (ITR) sobre pequenas as glebas rurais, assim definidas em lei, quando as explore o proprietário que não possua outro imóvel $\left(\mathrm{CF}, \operatorname{art} .153, \S 4^{\circ}, \mathrm{II}\right)$.

Além do mais, Alexandre (2019, p. 212), classifica as imunidades quanto à origem, vejase: ontológicas e políticas. Para ele, são ontológicas as imunidades que existiriam mesmo sem previsão expressa do texto constitucional, vez que são fundamentais para o atendimento ao princípio da isonomia e ao pacto federativo, exemplificando com as imunidades das instituições de educação e assistência social sem fins lucrativos (CF, art.150, VI, c). Para ele, também é ontológica a imunidade recíproca - entre os entes, não pode haver tributação (CF, art.150, VI, a), porque ela se configura em cláusula protetiva do pacto federativo. 
Prossegue o autor, ao designar que as imunidades de caráter político são aquelas que almejam à proteção de outros princípios em virtude de uma opção política do constituinte, tal como é o caso da imunidade dos templos de qualquer culto e dos livros, jornais, periódicos e do papel destinado à sua impressão.

Finalmente, Alexandre (2019, p. 212-213), classifica as imunidades quanto ao alcance: gerais e específicas. A imunidade geral abrangeria vedações a todos os entes tributantes em relação a diversos tributos, por exemplo, art.150, VI, da CF/1988, que impede qualquer ente político de instituir qualquer imposto sobre patrimônio, renda e serviços das diversas entidades.

Por outro lado, o legislador pode restringir a aplicação da imunidade a um determinado tributo de competência de determinada pessoa jurídica, de forma a atender certa conveniência, por exemplo: as imunidades ao IPI e ao ICMS nas operações de exportação (Arts.153, § $3^{\circ}$, III e $155, \S 2^{\circ}, \mathrm{X}$, a, ambos da $\mathrm{CF} / 1988$ ) e a imunidade ao ITBI que beneficia diversas operações societárias (art.156, § 2 ${ }^{\circ}$ I da CF/1988). Referidas situações são classificadas como imunidades específicas ou tópicas (ALEXANDRE, 2019).

Carvalho (2019, p. 222) cita outras hipóteses de imunidades previstas no texto constitucional brasileiro. São elas: Art.153, $\S 4^{\circ}$, II ao proclamar que o imposto territorial rural não incidirá sobre pequenas glebas rurais; e a imunidade do ouro em relação a todos os impostos que não aquele previsto no art. $153, \mathrm{~V}$.

Sem a pretensão de esgotar o tema, pode-se dizer que todas as imunidades estão elencadas ao longo do texto constitucional, apesar de que, na maioria dos casos, a referência a elas ocorrer de modo confuso e pelo uso de termos equivocados, por meio das expressões "são isentos" ou ainda "é vedado". Todos, inclusive o STF, já firmaram o entendimento que se trata, verdadeiramente, de imunidades tributárias.

\title{
b. ISENÇÃO
}

A Lei n. 5.172, de 25 de outubro de 1966, denominada Código Tributário Nacional (CTN), elenca a isenção como hipótese de exclusão do crédito tributário no art. 175, verbis:

\author{
(...) Art.175. Excluem o crédito tributário: \\ I - A isenção; \\ II - A anistia. \\ Parágrafo Único. A exclusão do crédito tributário não dispensa o cumprimento \\ das obrigações acessórias, dependentes da obrigação principal cujo crédito seja \\ excluído, ou dela consequente.
}

Assim, é consenso doutrinário que a obrigação tributária nasce com o surgimento do fato gerador. Todavia, devido a uma situação prevista em lei (isenção), o lançamento não deverá ser realizado e, consequentemente, o tributo não deverá ser cobrado, sendo, portanto, isento.

A isenção só será válida se for concedida por meio de lei específica, e os beneficiários somente poderão usufruir seus benefícios se cumprirem os requisitos estabelecidos no referido diploma legal. Adicionalmente, ressalta-se que a isenção pode ser feita por prazo determinado ou indeterminado e, ainda, de modo condicionado ou incondicionado, tudo conforme a previsão legal. Ela poderá ser extinta por caducidade ou pela edição de nova lei em sentido contrário.

\section{c. DIFERENÇA ENTRE IMUNIDADE E ISENÇÃO}

Imunidade tributária e isenção são institutos completamente distintos, apesar de que, na prática, ambos acarretam a dispensa do pagamento de determinado tributo. 


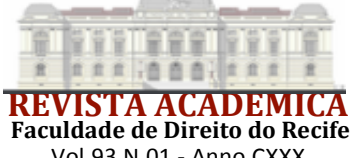

veluade de Direito do Recife

Vol. 93 N.01 - Anno CXXX

No ensinamento de Alexandre (2019, p. 207-209), as imunidades tratam de limitações constitucionais ao poder de tributar consistentes numa delimitação da competência tributária constitucionalmente conferida aos entes políticos. Por outro lado, a isenção consiste na dispensa legal do pagamento do tributo, uma vez que o ente político tem a competência para instituir o tributo e, ao fazê-lo, opta por dispensar o pagamento em situações legalmente previstas.

Para o citado autor, a principal diferenciação existente entre a isenção e a imunidade é esta: a isenção opera no âmbito do exercício da competência, enquanto a imunidade opera no âmbito da própria delimitação de competência. A consequência disso é que, como a imunidade delimita competência constitucionalmente atribuída, é sempre prevista na própria constituição. Já a isenção, esta será sempre prevista em lei.

Segundo Mazza (2019, p. 312) imunidade e isenção são institutos inconfundíveis, pois, enquanto imunidade é uma norma constitucional que limita a competência tributária, afastando sua incidência sobre determinados itens ou pessoas, operando ainda no aplano constitucional e interagindo com as regras que definem a competência para a instituição de tributos antes que o fato gerador ocorra; a isenção é um benefício legal concedido pelo legislador que, excluindo o crédito tributário (art.175 do CTN), libera o contribuinte de realizar o pagamento do tributo após a ocorrência do fato gerador.

No entender de Sabbag (2012, p. 287), a imunidade é instituto de sede constitucional. Enquanto a norma imunizante revela uma dispensa constitucional de tributo, a regra isentiva indica dispensa legal, já no campo da tributação. A isenção inibe o lançamento do tributo, tendo ocorrido o fato gerador e tendo nascido, consequentemente, o liame jurídico-obrigacional. $\mathrm{Na}$ imunidade, tal situação não ocorre, uma vez que a norma imunizadora ainda está fora do campo de incidência do tributo, representando um obstáculo à própria incidência de tributos sobre determinados fatos, situações ou pessoas.

O STF considera que a isenção inibe o lançamento do tributo, enquanto, na imunidade, não há que falar sequer em lançamento do tributo, pois nem mesmo houve uma relação jurídicoobrigacional. A isenção pode deixar de existir, se acaso cessarem as condições predeterminadas ou pela edição de uma nova norma versando em sentido oposto. Isso, no entanto, não ocorre no caso das imunidades, que cessariam somente por meio de Emenda Constitucional.

\section{d. NATUREZA JURÍDICA DOS TRIBUTOS PREVISTOS NO MODELO ZFM}

Após relevantes esclarecimentos conceituais, avança-se para a temática fulcral deste trabalho. Questiona-se: afinal, quais seriam as naturezas jurídicas das desonerações tributárias estipuladas pelo modelo da ZFM? Seriam elas isenções ou imunidades?

A primeira observação a ser feita é a de que, segundo Ramos Filho (2019, p.43), o Decreto-Lei n. 288, que instituiu os benefícios fiscais da ZFM, somente o fez expressamente no tocante aos impostos federais. Com relação aos tributos estaduais e municipais, os benefícios foram albergados pela legislação infraconstitucional.

Ao analisar a natureza jurídica dos incentivos fiscais estabelecidos pelo modelo ZFM, logo se vislumbra uma controvérsia. É sabido que as imunidades previstas no corpo da Constituição de 1988 não têm prazo de duração estabelecido, sendo, portanto, perenes. Como, por exemplo, as imunidades previstas no art.150, inciso VI, alíneas $a, b, c, d$ e $e$ da CF/88:

Art. 150. Sem prejuízo de outras garantias asseguradas ao contribuinte, é vedado à União, aos Estados, ao Distrito Federal e aos Municípios:

(...)

VI - instituir impostos sobre:

a) patrimônio, renda ou serviços, uns dos outros;

b) templos de qualquer culto; 


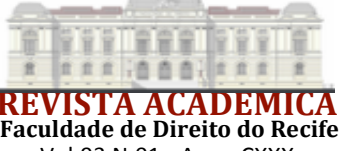

Faculdade de Direito do Recife

Vol.93 N.01 - Anno CXXX

c) patrimônio, renda ou serviços dos partidos políticos, inclusive suas fundações, das entidades sindicais dos trabalhadores, das instituições de educação e de assistência social, sem fins lucrativos, atendidos os requisitos da lei;

d) livros, jornais, periódicos e o papel destinado a sua impressão.

e) fonogramas e videofonogramas musicais produzidos no Brasil contendo obras musicais ou litero musicais de autores brasileiros e/ou obras em geral interpretadas por artistas brasileiros bem como os suportes materiais ou arquivos digitais que os contenham, salvo na etapa de replicação industrial de mídias ópticas de leitura a laser (BRASIL, 1988).

Além disso, as imunidades tributarias são consideradas cláusulas pétreas, haja vista a interpretação de que se configuram como garantias constitucionais asseguradas ao contribuinte. Assim determina o art. 60, $\S 4^{\circ}$, inciso IV, da Constituição de 1988:

Art. 60. A Constituição poderá ser emendada mediante proposta:

(...)

$\S 4^{\circ}$ Não será objeto de deliberação a proposta de emenda tendente a abolir:

I - a forma federativa de Estado;

II - o voto direto, secreto, universal e periódico;

III - a separação dos Poderes;

IV - os direitos e garantias individuais. (BRASIL, 1988).

Entretanto, os benefícios fiscais da ZFM elencados pelo Decreto-Lei n. 288/67 foram expressamente recepcionados pelo art. 40 do ADCT, ganhando "status" constitucional, todavia, com seu prazo de duração preestabelecido. Nesse sentido, surge a questão: figurando na $\mathrm{CF} / 88$, tais benefícios seriam isenção por prazo determinado ou seriam imunidades?

Duas correntes doutrinárias se propõem a responder esse questionamento. A primeira delas considera que todos os incentivos atribuídos pelo modelo ZFM são considerados como isenção, ainda que tenham sido recepcionados pela Constituição Federal de 1988. O professor Ramos Filho (2019, p. 88, 93) filia-se a essa corrente e cita Paulo Ramos de Barros Carvalho, José Souto Maior Borges e Sacha Navarro Carvalho, concluindo:

Nem o art. $4^{\circ}$ do Decreto-lei 288/1967, ao equiparar a remessa para a ZFM a uma exportação para o exterior, criou uma imunidade ao ICMS, como também não o fez a Constituição de 1988 ao recepcionar, nos arts. 40 e 92 do ADCT, os incentivos da Zona Franca de Manaus. Não foram os incentivos que foram constitucionalizados, mas a garantia de sua proteção é que foi.

A segunda corrente considera tal concessão como imunidade tributária. Nesse sentido, Ramos Filho (2019, p. 86) cita os doutrinadores Elson Rodrigues de Andrade e Marco Aurélio Greco como expoentes dessa tese. A meu ver, trata-se de imunidade, já que tais benefícios não poderiam deixar de existir antes do prazo de duração previsto, mesmo que fossem revogados por uma Emenda Constitucional, a qual deveria, inclusive, ser declarada inconstitucional por ofender, entre outras coisas, a cláusula pétrea prevista no art. $60, \S 4^{\circ}$, inciso IV, da CF/1988 e os princípios da segurança jurídica e da isonomia.

Nesse sentido, apresenta-se o julgado da ADI 310, cuja relatora foi a ministra Carmen Lúcia. A ementa abaixo transcrita faz menção à imunidade tributária dos incentivos da ZFM: 
(...) EMENTA: AÇÃO DIRETA DE INCONSTITUCIONALIDADE. CONVÊNIOS SOBRE ICMS NS. 01, 02 E 06 DE 1990: REVOGAÇÃO DE BENEFÍCIOS FISCAIS INSTITUIIDOS ANTES DO ADVENTO DA ORDEM CONSTITUCIONAL DE 1998, ENVOLVENDO BENS DESTINADOS À ZONA FRANCA DE MANAUS. 1. Não se há cogitar de inconstitucionalidade indireta, por violação de normas interpostas, na espécie vertente: a questão está na definição do alcance do art. 40 do Ato das Disposições Constitucionais Transitórias, a ser, se esta norma de vigência temporária teria permitido a recepção do elenco pré-constitucional de incentivos à Zona Franca de Manaus, ainda que incompatíveis com o sistema constitucional do ICMS instituído desde 1988, no qual se insere a competência das unidades federativas para, mediante convênio, dispor sobre isenção e incentivos fiscais do novo tributo (art. 155, § $2^{\circ}$, inciso XII, letra ' $\mathrm{g}$ ', da Constituição da República). 2. O quadro normativo pré-constitucional de incentivo fiscal à Zona Franca de Manaus constitucionalizou-se pelo art. 40 do Ato das Disposições Constitucionais Transitórias, adquirindo, por força dessa regra transitória, natureza de imunidade tributária, persistindo vigente a equiparação procedida pelo art. $4^{\circ}$ do Decreto-Lei n. 288/1967, cujo propósito foi atrair a não incidência do imposto sobre circulação de mercadorias estipulada no art. 23 , inc. II, $\S 7^{\circ}$, da Carta pretérita, desonerando, assim, a saída de mercadorias do território nacional para consumo ou industrialização na Zona Franca de Manaus. 3. A determinação expressa de manutenção do conjunto de incentivos fiscais referentes à Zona Franca de Manaus, extraídos, obviamente, da legislação pré-constitucional, exige a não incidência do ICMS sobre as operações de saída de mercadorias para aquela área de livre comércio, sob pena de se proceder a uma redução do quadro fiscal expressamente mantido por dispositivo constitucional específico e transitório.

No julgamento do Recurso Extraordinário (RE) n. 568417 AgR/RS - Rio Grande do Sul, o ministro-relator Dias Toffoli também fez referência, na ementa desse julgado, ao termo "imunidade tributária" quando tratou dos incentivos fiscais da ZFM:

(...) EMENTA Agravo regimental no recurso extraordinário. PIS e COFINS. Produtos destinados à Zona Franca de Manaus. DL n. 288/67. Natureza infraconstitucional da controvérsia. Ofensa reflexa. Discussão sob o enfoque do art. 40, parágrafo único, do ADCT. Entendimento do STF na ADI 2.348-MC. MP no 2.037-24/00. Suspensão da eficácia. 1. As discussões relativas à isenção concedida na venda de produtos destinados à Zona Franca de Manaus, à luz do Decreto-lei $n^{0}$ 288/97, ensejam reinterpretação de normas infraconstitucionais, sendo que a suposta afronta à Constituição, se ocorresse, seria indireta. Precedentes. 2. O Supremo Tribunal Federal, no julgamento da ADI 2.348-MC, Relator o Ministro Marco Aurélio, DJ de 7/11/03, apreciando a questão, afastou a eficácia de dispositivos da MP n ${ }^{\circ}$ 2.037-24/2000, à luz do art. 40 do ADCT, no intuito de preservar a imunidade tributária constitucionalmente deferida à Zona Franca de Manaus. Precedentes. 3. Agravo regimental não provido.

Em outro importante julgado, o RE 1072586/CE - Ceará - Recurso Extraordinário, que teve como relator o Ministro Edson Fachin, as vendas destinadas à ZFM foram equiparadas à exportação, sendo, portanto, imunes. Isso se dá por força do art.153, $\S 3^{\circ}, \mathrm{III}$ da $\mathrm{CF} / 88$ :

(...) Decisão: Trata-se recurso extraordinário interposto em face de acórdão do Tribunal Regional Federal da $5^{\text {a }}$ Região, cuja ementa reproduz-se:

TRIBUTÁRIO. MANDADO DE SEGURANÇA. CONTRIBUIÇÕES SOBRE A RECEITA BRUTA (PIS E COFINS). EXCLUSÃO DA BASE DE 
CÁLCULO. VENDA EFETUADA PARA A ZONA FRANCA DE MANAUS. OPERAÇÃO EQUIPARADA À EXPORTAÇÃO. ART. $4^{\circ}$, DO DECRETOLEI N ${ }^{\circ} 288 / 67$, RECEPCIONADO PELO

ART. 40, DO ADCT. ART. $9^{\circ}$, INCISO II, DA LEI No 12.546/11. 1. Mandado de Segurança impetrado visando o reconhecimento - como receita equiparada à exportação - a decorrente de venda para Zona Franca de Manaus e Áreas de Livre Comércio, para fins de exclusão da base de cálculo da Contribuição Previdenciária sobre a Receita Bruta (PIS e COFINS), nos termos do art. $9^{\circ}$, inciso II, da Lei $\mathrm{n}^{\circ}$ 12.546/2011. Sentença concessiva da ordem. 2. A Zona Franca de Manaus é área de livre comércio de importação e exportação e de incentivos fiscais especiais, equivalendo a uma exportação brasileira para o estrangeiro, para todos os efeitos fiscais. O art. 40, do ADCT, recepcionou o Decreto-Lei $n^{\circ}$ 288/67. 3. A Lei n. 12.546/2011, em seu art. 9º inciso II, expressamente exclui da base de cálculo das contribuições a receita decorrente das exportações. Sentença que está em consonância com o precedente do Órgão Plenário deste Tribunal, no julgamento da Arguição de Inconstitucionalidade na AMS 87396 (rel. Des. Fed. Geraldo Apoliano, Publicado no DE 16/06/2009, p. 203). Apelação e Remessa Necessária improvidas.

Tal decisão foi corroborada no julgamento do ARE 997126/DF - Distrito Federal Recurso Extraordinário com Agravo, cujo ministro-relator foi Roberto Barroso e cujo acórdão foi publicado no dia 24 de outubro de 2016. Confira-se trecho:

TRIBUTÁRIO. PIS - COFINS. ISENÇÃO SOBRE RECEITAS DECORRENTES DAS OPERAÇÕES COMERCIAIS REALIZADAS NA ZONA FRANCA DE MANAUS. DECRETO-LEI 288/1967. ART. 40 DO ADCT. COMPENSAÇÃO. POSSIBILIDADE.

1. A venda de mercadorias para a Zona Franca de Manaus equivale a exportação de produtos brasileiros para país estrangeiro, com todas as benesses fiscais constantes na legislação de regência, conforme disposto no art. $4^{\circ}$ do DecretoLei 288/1967, que está em vigor em razão do art. 92 do ADCT, acrescido pela Emenda Constitucional 42, de 19/12/2003, que prorrogou por mais dez anos o prazo estabelecido no art. 40 do ADCT.

2. A legislação referente ao PIS e à COFINS prevê expressamente que essas contribuições não incidirão sobre as receitas decorrentes das operações de exportação de mercadorias para o exterior. Não incidem também sobre as receitas decorrentes das operações realizadas na Zona Franca de Manaus, por força do art. 40 do ADCT.

(...) quanto à discussão sob o enfoque do art. 40, parágrafo único, do ADCT, melhor sorte não socorre a recorrente, pois no julgamento da ADI 2.348-MC, Relator o Ministro Marco Aurélio, DJ de 7/11/03, o Supremo Tribunal Federal, ao apreciar a questão, afastou a eficácia de dispositivos da MP $\mathrm{n}^{\circ} 2.037$ 24/2000, no intuito de preservar a imunidade tributária constitucionalmente deferida à Zona Franca de Manaus. Na ocasião, o Ministro Marco Aurélio assentou, em seu voto, a contrariedade ao art. 40 do ADCT, "porque este absorveu a legislação em vigor, à época, e o Decreto-Lei $n^{\circ} 288$ é explícito quanto à equiparação da importação por Manaus à exportação de Manaus. $\mathrm{O}$ julgado na ADI $n^{\circ}$ 2.348-MC restou assim ementado:

$\mathrm{Na}$ mesma direção: ARE 913.438/DF, Rel. Min. Cármen Lúcia; RE 540.313/PR, Rel. ${ }^{\mathrm{a}}$ Min. ${ }^{\mathrm{a}}$ Ellen Gracie; e RE 756.657/MT.

Foi em igual sentido o julgamento do ARE 993658/AM - Recurso Extraordinário com Agravo, de relatoria do ministro Dias Toffoli, no dia 27 de setembro de 2016. Veja-se: 
(...) 4. As operações com mercadorias destinadas à Zona Franca de Manaus são equiparadas à exportação para efeitos fiscais (Decreto-Lei 288/67, art. $4^{\circ}$ ), caso em que sobre elas não incidem as contribuições ao PIS e à Cofins.

5. O referido benefício fiscal também alcança as empresas sediadas na própria ZFM que vendem seus produtos para outras na mesma localidade. 'Interpretação calcada nas finalidades que presidiram a criação da Zona Franca, estampadas no próprio DL 288/67, e na observância irrestrita dos princípios constitucionais que impõem o combate às desigualdades sócio-regionais' (REsp 1.276.540-AM, r. Ministro Castro Meira, $2^{\mathrm{a}}$ Turma do STJ).

(...) por outro lado, quanto à discussão sob o enfoque do art. 40, parágrafo único, do ADCT, melhor sorte não socorre a recorrente, pois no julgamento da ADI n ${ }^{\circ}$ 2.348-MC, Rel. o Min. Marco Aurélio, DJ de 7/11/03, o STF, ao apreciar a questão, afastou a eficácia de dispositivos da MP no 2.037-24/2000, no intuito de preservar a imunidade tributária constitucionalmente deferida à Zona Franca de Manaus. Na ocasião, o Ministro Marco Aurélio assentou, em seu voto, a contrariedade ao art. 40 do ADCT, "porque este absorveu a legislação em vigor, à época, e o Decreto-Lei $\mathrm{n}^{\circ} 288$ é explícito quanto à equiparação da importação por Manaus à exportação de Manaus".

O julgado proferido na ADI ${ }^{\circ}$ 2.348-MC restou assim ementado:

Na mesma direção: ARE no 913.438/DF, Relatora a Ministra Cármen Lúcia, DJe de 24/9/15; RE no 756.657/MT, de minha relatoria, DJe de 29/5/14.

Diante do complexo cenário jurisprudencial representado pelos enxertos de decisões emblemáticas exaradas pela Corte Constitucional brasileira, o próximo passo é pontuar sobre a natureza jurídica de cada incentivo fiscal já estabelecido no modelo da Zona Franca de Manaus, sejam eles federais, estaduais ou municipais.

\section{i. Incentivos Federais}

Nesse contexto, importa salientar com mais precisão a natureza jurídica dos incentivos, dando início pelos federais, conforme minudenciado nas subseções seguintes.

1. Redução de até $88 \%$ do Imposto de Importação (II) sobre os insumos destinados à industrialização

Natureza jurídica: Imunidade tributária

Quadro 1 - Base legal Imposto de Importação (II)

\begin{tabular}{|c|c|}
\hline LEI & ARTIGO \\
\hline $\mathrm{CF} / 1988$ & $153, \mathrm{I}$ \\
\hline $\mathrm{DL}-288 / 1967$ & $3^{\text {o }}$ \\
\hline
\end{tabular}

Fonte: Da pesquisa (2020).

2. Isenção do Imposto sobre Produtos Industrializados (IPI)

Natureza jurídica - Imunidade Tributária 
Quadro 2 - Imposto sobre Produtos Industrializados (IPI)

\begin{tabular}{|c|c|}
\hline LEI & ARTIGO \\
\hline $\mathrm{CF} / 1988$ & $153, \mathrm{IV}$ \\
\hline $\mathrm{DL}-288 / 1967$ & $3^{\text {o }}$ \\
\hline
\end{tabular}

Fonte: Da pesquisa (2020).

3. Redução de $75 \%$ do Imposto de Renda de Pessoa Jurídica (IRPJ), inclusive adicionais de empreendimentos classificados como prioritários para o desenvolvimento regional, calculados com base no Lucro da Exploração até 2013.

Natureza jurídica - Imunidade Tributária

Quadro 3 - Redução de 75\% do Imposto de Renda de Pessoa Jurídica (IRPJ)

\begin{tabular}{|c|c|}
\hline LEI & ARTIGO \\
\hline $\mathrm{CF} / 1988$ & $153, \mathrm{I}$ \\
\hline $\mathrm{DL}-288 / 1967$ & $3^{\text {o }}$ \\
\hline
\end{tabular}

Fonte: Da pesquisa (2020).

4. Isenção da Contribuição para o PIS/PASEP e da Cofins nas operações internas na Zona Franca de Manaus

Natureza jurídica - Imunidade Tributária

Quadro 4 - Isenção da Contribuição para o PIS/PASEP e da Cofins

\begin{tabular}{|c|c|}
\hline LEI & ARTIGO \\
\hline $\mathrm{CF} / 1988$ & $149, \S 2^{\text {o }}, \mathrm{I}$ \\
\hline $\mathrm{DL}-288 / 1967$ & $4^{\text {o }}$ \\
\hline
\end{tabular}

Fonte: Da pesquisa (2020).

Nesse sentido foi o julgamento, de 19 de abril de 2016, no ARE 957268/AM - Recurso Extraordinário com Agravo, cujo relator foi o ministro Luiz Fux. No julgado em comento, se reconheceu a existência do benefício da exclusão da base de cálculo do PIS e da Cofins para as vendas de produtos por empresa localizada na ZFM para outra da mesma localidade:

(...) 4. No que tange à matéria de fundo, o art. 40 do ADCT da Constituição Federal de 1988 preservou a Zona Franca de Manaus como área de livre 


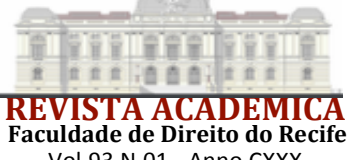

Vol.93 N.01-

comércio recepcionando o Decreto-lei n. 288/67, que prevê expressamente que a exportação de mercadorias de origem nacional para a Zona Franca de Manaus, ou reexportação para o estrangeiro, será, para todos os efeitos fiscais, equivalente a uma exportação brasileira para o exterior.

5. A legislação referente ao PIS e à COFINS prevê expressamente que as mencionadas contribuições não incidirão sobre as receitas decorrentes das operações de exportação de mercadorias para o exterior, razão por que se aplica àquelas destinadas à Zona Franca de Manaus, por força do Decreto-lei n. 288/67 e no art. 40 do ADCT.

6. No benefício da exclusão da base de cálculo do PIS e da COFINS devem ser incluídos os valores resultantes de vendas de produtos por empresa localizada na Zona Franca de Manaus para outra da mesma localidade, sob pena de ofensa ao disposto no Decreto-lei n. 288/67, aos arts. 40 e 92 do ACDT da CF/88, e o princípio da isonomia.

É o relatório. DECIDO. O agravo não merece prosperar. Por fim, no que diz respeito aos artigos 40 e 92 do Ato das Disposições Constitucionais Transitórias, observe-se que a cobrança da contribuição ao PIS e da Cofins, quando sub judice a controvérsia acerca da isenção do tributo incidente sobre as receitas decorrentes das operações de venda às empresas instaladas na Zona Franca de Manaus, demanda a análise da legislação infraconstitucional, o que inviabiliza a admissibilidade do recurso extraordinário. Nesse sentido, ARE 634.512-AgR, Rel. Min. Dias Toffoli, Primeira Turma, DJe de 30/9/2013, e RE 640.653-AgR, Rel. Min. Gilmar Mendes, Segunda Turma, DJe de 30/9/2011, com a seguinte ementa: "Agravo interno em recurso extraordinário.

Em outro julgado, de 10 de outubro de 2014, qual seja o RE 698820/DF - Distrito Federal/Recurso Extraordinário, cujo relator foi o ministro Roberto Barroso, reconheceu-se que as vendas destinadas à ZFM são equiparadas às exportações, sendo, portanto, imunes:

(...) DECISÃO: Trata-se de recurso extraordinário interposto contra acórdão da $2^{\text {a }}$ Turma do Tribunal Regional Federal da $4^{\text {a }}$ Região, assim ementado:

"TRIBUTÁRIO. PIS. COFINS. PRESCRIÇÃ̃O. RECEITAS DE VENDAS EFETUADAS A EMPRESAS SITUADAS NA ZONA FRANCA DE MANAUS. PRESCRIÇÃO. ART. $4^{\circ}$ DO DL N. 288/67. ART. 40 DO ADCT. ART. 14 DA MEDIDA PROVISÓRIA N. 2.037/00. ADI N. 2.348.; COMPENSAÇÃO CORREÇÃO MONETÁRIA E JUROS. VERBA HONORÁRIA.

2. Nos termos do Decreto-Lei $\mathrm{n}^{\circ} 288$, de 1976, as compras e vendas realizadas para empresas situadas na Zona Franca de Manaus foram equiparadas às operações de exportação, conforme se extrai do art. $4^{\circ}$ do referido Diploma legal.

3. O art. 40 do Ato das Disposições Constitucionais Transitórias objetiva a manutenção da Zona Franca de Manaus, com suas características de área de livre comércio, de exportação e importação, e de incentivos fiscais, pelo prazo de vinte e cinco anos, a contar da promulgação da Constituição.

4. Ao apreciar a medida cautelar em ADI n. 2.348, em 07.12.2000, o Pretório Excelso, por unanimidade de votos, entendeu por bem suspender, com efeitos ex nunc e até o final do julgamento da ação direta, a eficácia da expressão 'a Zona Franca de Manaus', contida no inciso I do $\S 2^{\circ}$ do art. 14 da Medida Provisória n. 2.037/2000. O dispositivo que teve sua eficácia suspensa excluía da isenção de PIS e COFINS as receitas de vendas efetuadas a empresas situadas na Zona Franca de Manaus. 
6. Assim, a contribuição ao PIS e a COFINS não incidem sobre as receitas provenientes de vendas de mercadorias para a ZFM, que merecem o mesmo tratamento fiscal dispensado às vendas ao exterior.

3. Agravo regimental não provido" (RE 568.417-AgR, Rel. Min. Dias Toffoli) "AGRAVO REGIMENTAL NO RECURSO EXTRAORDINÁRIO. DIREITO TRIBUTÁRIO. PIS E COFINS. ISENÇÃO. RECEITAS ORIUNDAS DAS VENDAS DE MERCADORAIS PARA A ZONA FRANCA DE MANAUS. LEGISLAÇÃO INFRACONSTITUCIONAL. OFENSA REFLEXA. PRECEDENTES DA CORTE. RECURSO DESPROVIDO.

1. A isenção de PIS e COFINS nas receitas oriundas das vendas de mercadorias para a Zona Franca de Manaus é matéria que impõe ao E. STF o exame da legislação infraconstitucional. Por isso que eventual ofensa à Constituição somente ocorreria de forma indireta, circunstância que inviabiliza a admissão do recurso extraordinário.

2. Precedentes no mesmo sentido: RE n. 539590-AgR, Relatora a Ministra Ellen Gracie, DJ de 26.4.2011; RE n. 456336-AgR, Relator o Ministro Celso de Mello, DJ de 8.11.2010.

Em vista do exposto, resta claro o entendimento do Supremo Tribunal Federal quanto ao reconhecimento de que o incentivo ora analisado tem natureza de imunidade tributária.

\section{ii. Incentivos Estaduais}

Restituição parcial ou total, variando de $55 \%$ a $100 \%$ - dependendo do projeto - do Imposto sobre Operações Relativas à Circulação de Mercadorias e sobre Prestação de Serviços de Transporte Interestadual e Intermunicipal e de Comunicação (ICMS).

Natureza jurídica: isenção heterônoma.

\begin{tabular}{|c|c|}
\hline \multicolumn{2}{|c|}{ Quadro 5 - Isenção do ICMS } \\
\hline LEI & ARTIGO \\
\hline CF/1988 & 151, III \\
\hline DL $-288 / 1967$ & $4^{\circ}$ \\
\hline
\end{tabular}

Fonte: Da pesquisa (2020).

\section{iii. Incentivos Municipais}

Isenção do Imposto sobre Propriedade Predial e Territorial Urbana, Taxas de Serviços de Coleta de Lixo, de Limpeza Pública, de Conservação de Vias e Logradouros Públicos e Taxas de Licença a empresas que geram pelo menos quinhentos empregos, de forma direta, no início da atividade, mantendo o número para gozar do benefício. (Lei Municipal n. 427/1998).

Natureza jurídica: isenção.

Quadro 6 - Incentivos Municipais

\begin{tabular}{|c|c|}
\hline LEI & ARTIGO \\
\hline
\end{tabular}




\begin{tabular}{|c|c|} 
CF/1988 & $153, \mathrm{I}$ \\
\hline DL - 288/1967 & $3^{\circ}$ \\
\hline $\begin{array}{c}\text { Lei Orgânica Município - } \\
\text { Manaus }\end{array}$ & 402 \\
\hline Lei Municipal nº 427/1998 & \\
\hline
\end{tabular}

Fonte: Da pesquisa (2020).

iv. Síntese - Base legal e natureza jurídica dos incentivos à ZFM

Haja vista todo o exposto, abaixo se apresenta um quadro sinótico contendo a natureza jurídica de todos os incentivos fiscais propostos no âmbito do modelo ZFM.

Quadro 7 - Base legal e natureza jurídica dos incentivos à ZFM

\begin{tabular}{|c|c|c|}
\hline TRIBUTO & BASE LEGAL & NATUREZA JURÍDICA \\
\hline $\begin{array}{l}\text { Imposto de Importação } \\
\text { (II) }\end{array}$ & $\begin{array}{l}\text { Art. } 153, \text { I CF/88 e Art. } 3^{\circ} \text { Decreto- Lei } \\
288 / 1967\end{array}$ & Imunidade Tributária \\
\hline IPI & $\begin{array}{l}\text { Art. 153, IV da CF/88 e Art. } 3^{\circ} \\
\text { Decreto- Lei } 288 / 1967\end{array}$ & Imunidade Tributária \\
\hline IRPJ & $\begin{array}{l}\text { Artigo } 173 \S 1^{\circ} \text { da } C F / 88 \text { e Decreto } \\
3.000 / 1999\end{array}$ & Imunidade Tributária \\
\hline PIS/COFINS & $\begin{array}{l}\text { Art.149, } \S 2^{\circ}, \text { II CF/88 e Art. } 4^{\circ} \\
\text { Decreto- Lei } 288 / 1967\end{array}$ & Imunidade Tributária \\
\hline ICMS & $\begin{array}{l}\text { Art.151, III CF/88, Art. } 4^{\circ} \text { Decreto- Lei } \\
288 / 1967 \text { e Art.149 e Art.150 } \\
\text { Constituição Estado do Amazonas }\end{array}$ & Isenção heterônoma \\
\hline IPTU & $\begin{array}{l}\text { Art.156 I CF/88, art.402 Lei Orgânica } \\
\text { Município - Manaus e Lei Municipal } \\
n^{\circ} 427 / 1998\end{array}$ & Isenção \\
\hline
\end{tabular}

Fonte: Da pesquisa (2020)

Conforme a pesquisa, somam seis os tributos que têm incentivos para a Zona Franca de Manaus, dentre os quais quatro são federais, um é estadual e outro é municipal. Frisa-se que todo o conjunto de incentivos encontra permissivo para sua aplicação na Constituição Federal, explicitamente nos artigos 149, 151, 153 e 156, consoante os incisos especificados no quadro. Ademais, constatou-se haver legislação infraconstitucional dos respectivos entes federados dando conta de regulamentar a aplicação das referidas determinações de incentivo à ZFM. 
Outro ponto de grande relevância para este debate é a percepção de que, enquanto as imunidades só podem ser fixadas pela Constituição Federal, que o fez em relação aos tributos de federais (II, IPI, IRPJ e PIS/COFINS), os tributos estadual e municipal possuem respectiva natureza jurídica de isenção heterônoma (ICMS) e de isenção (IPTU), cujas previsões estão na Constituição Estadual do Amazonas e na Lei Orgânica do Município de Manaus.

\section{CONSIDERAÇÕES FINAIS}

Depois de contextualizar o problema a ser investigado e de definir os objetivos do mesmo, a análise foi iniciada pelos aspectos gerais da ZFM, em seção onde se realizou breve histórico do modelo, iniciando pelo Decreto-Lei n. 288/67. Esse Decreto é considerado como o marco legal de criação da Zona Franca, relevante política pública governamental que alcançou, basicamente, dois objetivos fundamentais. O primeiro foi ocupar o imenso vazio demográfico até então existente na Amazônia Ocidental, enquanto o segundo foi contribuir para desenvolver a região Norte, impactando positivamente na redução das desigualdades regionais no Brasil.

Em seguida, foram caracterizadas as cinco fases pelas quais a ZFM passou desde que fora criada. A primeira delas teve como atributo fundamental a predominância da atividade comercial, ao passo que, na fase atual, verifica-se como epicentro o aprofundamento da política industrial tecnológica, cujo enfoque é no adensamento tecnológico do parque industrial.

Outro ponto de análise deste trabalho foi o prazo de duração dos incentivos fiscais previstos para o modelo ZFM. Constatou-se que os referidos incentivos vêm sendo renovados desde o governo José Sarney, em 1986, culminado com a aprovação da Emenda Constitucional n. 83/2014, a qual estendeu a duração do modelo até 2073. Ressalta-se, neste ponto, que o prazo de vigência da ZFM somente poderá ser prorrogado por Emenda Constitucional.

Restou comprovado que as regras previstas no ADCT, ainda que sejam qualificadas como "transitórias", têm o mesmo status das que fazem parte do corpo da Constituição. Assim, como o modelo ZFM foi expressamente recepcionado pelo art. 40 do ADCT, conclui-se que a ZFM foi sim "constitucionalizada" na Carta de 1988. Os diversos julgados exarados pelo STF e apresentados ao longo do trabalho comprovam cabalmente o reconhecimento desse status.

Doutrinador do corpo docente da UFAM, o professor Ramos Filho sustenta que os fundamentos gerais da ZFM estão inseridos no inciso III do art. $3^{\circ}$ (erradicar a pobreza e a marginalização e reduzir as desigualdades sociais e regionais) da $\mathrm{CF} / 88$ e no inciso VII do art. 170 (redução das desigualdades regionais e sociais) da $\mathrm{CF} / 88$. Ao longo do texto constitucional, outros dispositivos também são sustentáculos à existência do modelo ZFM. São eles: art. 43, §2 $2^{\circ}$, III CF/88 (ação para combater as desigualdades regionais através de leis que estabeleçam isenções, reduções ou diferimento temporário de tributos federais); e exceção expressa no art. 151, I da CF/88 (admissão de concessão de incentivos fiscais destinados a promover o equilíbrio do desenvolvimento socioeconômico entre as diferentes regiões do país).

Prosseguindo, partiu-se para a definição dos tipos de incentivo concedidos pela ZFM, apurando a existência deles nas três esferas de governo (federal, estadual e municipal), quando puderam ser divididos em incentivos fiscais e incentivos parafiscais.

Após, enfrentou-se o problema central do estudo: estabelecer e/ou averiguar qual a real natureza jurídica dos benefícios fiscais presenteados pelo modelo ZFM, questionando ainda se seria possível considerá-los isenções, ou se, por outro lado, eles seriam imunidades tributárias.

Para tanto, foi necessário conceituar os dois institutos (imunidade e isenção) e, depois, estabelecer as principais diferenças entre ambos. Assim, imunidades são normas constitucionais que impedem o lançamento e a obrigação tributária, inexistindo, dessa forma, a relação jurídicotributária. No caso das isenções, estas pressupõem uma relação tributária, muito embora, devido a algumas situações previstas em lei, o tributo não pode ser cobrado. 
Em suma, foi estabelecida a natureza dos incentivos fiscais do modelo ZFM como: i. Imunidade tributária - imposto de importação (II), imposto sobre produtos industrializados (IPI), imposto de renda PJ (IRPJ), PIS e Cofins; ii. Isenção - IPTU e demais tributos concedidos pelo município de Manaus; e isenção - ICMS.

Indubitavelmente, o modelo ZFM tem cumprido os objetivos que foram estabelecidos desde a sua criação, contudo, é necessário promover ajustes nessa importante política pública. Enfatiza-se a necessidade de desenvolver tecnologias capazes de aproveitar o incomensurável potencial existente na floresta Amazônica, transformando a ZFM em verdadeiro polo de alta tecnologia cuja matéria-prima sejam os recursos do bioma Amazônico. Nesse sentido, crescente seria sua preponderância para além do papel de mero sustentáculo econômico e sua verdadeira contribuição para a conservação do meio ambiente e para o desenvolvimento regional.

\section{REFERÊNCIAS}

ALEXANDRE, Ricardo. Direito Tributário. 13. ed. rev., atua e ampl. Salvador: Editora Juspodivm, 2019.

BORGES, José Souto Maior. Teoria Geral da Isenção Tributária. 3. ed. São Paulo: Malheiros Editores, 2011.

BRASIL. [Constituição (1988)]. Constituição da República Federativa do Brasil de 1988. Disponível em: http://www.planalto.gov.br/ccivil_03/constituicao/constituicao.htm. Acesso em: 17 out. 2019.

BRASIL. Supremo Tribunal Federal. Ação Direta De Inconstitucionalidade: ADI 310. Relatora: Ministra Cármen Lúcia. Disponível em: http://www.stf.jus.br/portal/jurisprudencia/listarJurisprudencia.asp?s1=\%28ADI+CONVENIOS+ ICMS $+01+02 \% 29 \&$ base=baseAcordaos\&url=http://tinyurl.com/vg6rakx. Acesso em: $10 \mathrm{dez}$. 2019.

BRASIL. Supremo Tribunal Federal. Recurso Extraordinário com Agravo: ARE 957268/AM - Amazonas. Relator: Ministro Luiz Fux, Disponível em: http://www.stf.jus.br/portal/jurisprudencia/listarJurisprudencia.asp?s1=\%28ARE+957268\%29 \&base=baseAcordaos\&url=http://tinyurl.com/ushf26c. Acesso em: 10 dez. 2019.

BRASIL. Supremo Tribunal Federal. Recurso Extraordinário com Agravo: ARE 993658/AM - Amazonas. Relator: Ministro Dias Toffoli. Disponível em: http://www.stf.jus.br/portal/jurisprudencia/listarJurisprudencia.asp?s1=\%28\%28ARE+993658\% $29 \% 29+\mathrm{NAO}+\mathrm{S} \% 2 \mathrm{EPRES} \% 2 \mathrm{E} \&$ base=baseMonocraticas\&url=http://tinyurl.com/rhczjnq. Acesso: 10 dez. 2019.

BRASIL. Supremo Tribunal Federal. Recurso Extraordinário com Agravo: ARE 997126/DF. Relator: Ministro Roberto Barroso. Disponível em: http://www.stf.jus.br/portal/jurisprudencia/listarJurisprudencia.asp?s1=\%28\%28ARE+997126\% 29\%29+NA O+S\%2EPRES\%2E\&base=baseMonocraticas\&url=http://tinyurl.com/u8wt5t9. Acesso em: 10 dez. 2019.

BRASIL. Supremo Tribunal Federal. Recurso Extraordinário: RE 1072586 /CE - Ceará. Relator: Ministro Edson Fachin. Disponível http://www.stf.jus.br/portal/jurisprudencia/listarJurisprudencia.asp?s1=\%28\%28RE+1072586\%2 
9\%29+NAO+S\%2EPRES\%2E\&base=baseMonocraticas\&url=http://tinyurl.com/tvnqbh5.

Acesso em: 10 dez. 2019.

BRASIL. Supremo Tribunal Federal. Recurso Extraordinário: RE 160.486/SP. Relator: Ministro Celso de Mello. DJ: 11/10/1994. Disponível em: http://www.stf.jus.br/portal/jurisprudencia/listarJurisprudencia.asp?s1=\%28RE+160486\%29\&ba $\mathrm{se}=$ baseAco $\mathrm{rdaos} \& u r l=h t t p: / /$ tinyurl.com/y2b6y4ol. Acesso em: $10 \mathrm{dez} .2019$.

BRASIL. Supremo Tribunal Federal. Recurso Extraordinário: RE 568417 AgR/RS - Rio Grande do Sul. Relator: Ministro Relator Dias Toffoli. Disponível em: http://www.stf.jus.br/portal/jurisprudencia/listarJurisprudencia.asp?s1=\%28\%28RE\%29+N $\% \mathrm{BA}+568417 \% 29 \&$ base=baseAcordaos\&url=http://tinyurl.com/v494odp. Acesso em: $10 \mathrm{dez}$. 2019.

BRASIL. Supremo Tribunal Federal. Recurso Extraordinário: RE 698820/DF - DISTRITO FEDERAL. Rel.: Ministro Roberto Barroso. Disponível em: http://www.stf.jus.br/portal/jurisprudencia/listarJurisprudencia.asp?s1=\%28\%28RE+698820\%29 $\% 29+\mathrm{NAO}+\mathrm{S} \% 2 \mathrm{EPRES} \% 2 \mathrm{E} \&$ base=baseMonocraticas\&url=http://tinyurl.com/va3hoxp.

Acesso: 10 dez. 2019.

CARVAlho, Paulo de Barros. Curso de Direito Tributário. 30. ed. São Paulo: Saraiva Educação, 2019.

MANAUS. Lei Orgânica de Manaus. Disponível em: https://leismunicipais.com.br/leiorganica-manaus-am. Acesso: 20 jan. 2020.

MAZZA, Alexandre. Manual Direito Tributário. 5. ed. São Paulo: Editora Saraiva,2019.

RAMOS FILHO, C. A. de M. Sistema Tributário da Zona Franca de Manaus: proteção constitucional e incentivos fiscais. Curitiba: Centro de Estudos da Contemporaneidade, 2019.

SABBAG, Eduardo. Manual de Direito Tributário. 4. ed. São Paulo: Editora Saraiva, 2012.

SUFRAMA. Histórico da Zona Franca de Manaus (2019). Disponível em: http:/site.suframa.gov.br/assuntos/ modelo-zona-franca-de-manaus/o-que-e-o-projeto-zfm.

Acesso em: 17 out. 2019.

SUFRAMA. Incentivos Fiscais da Zona Franca de Manaus (2019). Disponível em: http://site.suframa.gov.br/ assuntos/ modelo-zona-franca-de-manaus/incentivos. Acesso em: 11 dez. 2019 